\title{
Banks Performance: Does Treasury Single Account matter? Evidence From Selected Commercial Banks in Tanzania
}

\author{
Erick Lusekelo Mwambuli \\ Faculty of Accounting, Banking and Finance, Institute of Finance Management (IFM), \\ Tanzania \\ E-mail: erickmwambuli@gmail.com
}

James Joseph Igoti

President's Office-Regional Administration and Local Government (PO-RALG), Tanzania

Received: August 13, 2020 Accepted: January 23, 2021 Published: January 26, 2021

doi:10.5296/csbm.v8i1.17518ＵRL: https://doi.org/10.5296/csbm.v8i1.17518

\begin{abstract}
This research assess the impacts of treasury single account on the financial performance of selected commercial banks in Tanzania. Data were collected from annual report of fourteen (14) commercial banks and Bank of Tanzania for the period of ten (10) years. The study used net interest margin as a dependent variable, government deposits as independent variable and both bank size and leverage were used as controlling variables. The data were analyzed by both EVIEWS 12 and STATA 16 using an ordinary least squares (OLS) regression model analysis. Our results concludes that treasury single account has impact on banks financial performance, the results shows that the government deposits has a significant positive effects on net interest margin. The possible reason for our results is the fact that Tanzania commercial banks were over relied on government funds rather than to mobilize funds from the un-banked among rural residents. Thus, the study recommend that for the commercial banks to improve their financial performance, they have to redefine the nature of competition, diversify economically and refocus on the original purposes for which they were set up- to collect deposits to customers especially from private sectors and un-banked Tanzanians.
\end{abstract}

Keyword: Net Interest Margin, Government Deposits, Treasury Single Account, Bank Performance and Tanzania 


\section{Introduction}

The government of Tanzania has been undergoing reforms in the public finance management in order to improve utilization of its financial resources in the way that will benefit the nation and boost economic development. Moreover, the East African Monetary Union (EAMU) convergence criteria requires partner state members (including Tanzania) to implement treasury single account (TSA) since 2017, the agreement reached by the East African Community partner states aimed at ensuring effective control and management of government resources. The primary objective of a TSA is to ensure effective aggregate control over government cash balances.TSA is a public accounting system under which all government revenue, receipts and income are collected into one single account, usually maintained by the country's central bank i.e. Bank of Tanzania (BOT) and all payments done through this account as well. The philosophical underpinning of TSA is primarily to ensure accountability of government revenue, enhance transparency and avoid misapplication and mismanagement of public funds (Pattanayak \& Fainboim, 2011). This measure has reduce the number of government accounts operated in the Tanzania commercial banks and BOT reduce costs related to services offered by commercial banks to the government and improve the financial position of the Paymaster General Account (i.e. Government Net Deficit Position). The concept of TSA may be new in principle but United Republic of Tanzania (URT) constitutional provisions have been with since 1977. The URT Constitution requires that all government revenue generation must be remitted into a single account (Consolidated Fund). Section 135(1) of 1977 as amended state that "All revenue derived from various sources for the use of the government of the United Republic, except for the type of revenue specified in sub article (2) of this Article, shall be paid into one special fund to be known as the Consolidated Fund of the government of the United Republic". Without adherence to the constitution provisions, the URT Government had been operating a fragmented banking arrangement with thousands of banks accounts in multiple commercial banks as the results increase the borrowing costs, sometimes government continue borrowing and paying additional interest charges to finance the expenditures of some agencies while other agencies keep idle balances in their bank accounts. On the other hand, the banking sector is the engine of any nation economy. The economic status of any country depends on how stable their banking industry is, therefore, any issue that affects commercial banks also has an impact on the economy of the country.

Given the fact that TSA is a new financial management system that is fully implemented in United Republic of Tanzania just few years ago, not much have been empirically documented especially on how it relates on commercial banks financial performance. Therefore, there is a research gap in this financial management arena, due to several reasons; firstly, yet is known as the effects of TSA policy on bank financial performance in Tanzania context. Secondly, there are very few empirical studies conducted in this area on international perspective, nevertheless researcher's results are mixed and inconclusive as the effects of TSA policy on bank financial performance is concern. Hence it is important to fill the research gap and examine the relationship between TSA and commercial banks performance. Therefore, the objective of this paper is to assess on how the commercial banks financial performance were affected due to the adoption of TSA policy by URT government. 
The rest of this paper is organized as follows. Section 2 presents the literature review and hypothesis development, the review covers empirical evidence relating to TSA and bank financial performance. Section 3 presents the research methodology used to collect data. Section 4 presents the findings and discussion of results. Section 5 presents the conclusion and recommendations from the study.

\section{Relevant Literature Review and Hypothesis Development}

The available prior studies on the relationship between the implementation of TSA and the financial performance of commercial banks have inconclusive and conflicting results. For instance, Ogbonna and Amuji (2018) carried out a research to assess the impacts of TSA on the performance of banks in Nigeria, the empirical evidence reveal that the performance of the commercial banks do not significantly depend on government deposits as there was no significant impact on banks performance due to TSA adoption, the assessed parameters were liquidity ratio, capital adequacy and credit to the customers for the two periods i.e. before adoption and after adoption of TSA. The researchers selected only two banks in Nigeria for the period of ten (10) years i.e. 2008-2017 to form the basis of conclusion. Furthermore, (Agbo et al., 2016) carried out the study to assess the effects of TSA on the performance and survival of deposit money banks in Nigeria, the study covered six (6) listed deposit money banks in Nigeria and audited report were involved and reveal that there is an insignificance impact on adoption of TSA on the performance of banks, the researchers assessed the performance of commercial banks by two parameters such as return on assets (ROA) and net interest margin (NIM) for the period of 2014-2015. Onuorah and Chigbu (2016) examine whether there is a significant impacts of federal government TSA deposits on commercial banks performance, the researchers measured TSA by three variables such as federal government demand deposit, federal government time deposits and federal government savings deposit and banks financial performance using both return on investment (ROI) and return on equity (ROE), the study found insignificant impact of TSA on banks financial performance using a research sample of six (6) commercial banks in Nigeria for five years 2012-2016.

On the other hand, other researchers found a negative effects of TSA on bank performance, for instance; Ighosewe and Ofor (2017) conducted the research to investigate the effects of TSA on bank performance in Nigeria, the study involves 125 management and staff of various commercial banks in four (4) regions, the study reveal that there is a negative significant relationship between TSA and profitability in the banking industry. The researchers measured TSA basing on the government deposit on the deposit money banks, while employed three variables to measure the bank performance including ROA for the period of two years i.e. 2015-2017.

Moreover, Olaoye and Talabi (2019) conducted the research to examine the impact of TSA on the financial performance of deposit money banks in Nigeria. It was discovered that TSA exerts a positive insignificant impact on all the indicators of profitability covered in their study except profit after tax (PAT) that has a negative insignificant impact. (Sabo et al., 2019) on their research titled TSA and bank performance, also found a positive and statistically significant relationship between bank performance and TSA in Nigeria throughout the study period. Lambe and Daniel (2019) conducted a research to examine the effect of TSA on the performance of deposit money banks in Nigeria and their study concludes that the introduction 
of the TSA has a significant effect on the performance of deposit money banks in Nigeria. Meanwhile, (Ndubuaku et al., 2017) on their study titled the impacts of TSA on the performance of banking sector in Nigeria, which involved 24 banks in Nigeria for the period of 2010-2015 reveal that TSA implementation has significance impacts to performance of banking industry.

Our study seeks to test the null hypothesis below;

H1 = TSA has a positive significant effect on banks financial performance

\section{Research Methodology}

This section focused on the overall methodology used in conducting this study.

\subsection{Scope, Target Population and Sample Size}

The scope of our study is all commercial banks in Tanzania operating before the implementation of TSA. According to the BOT directory there were forty (40) banks licensed to operate in Tanzania as at $31^{\text {st }}$ October 2017 (www.bot.go.tz/BankSupervision/Institutions). Therefore, the target population are all registered and licensed commercial banks in Tanzania for the period of ten (10) years from 2008 to 2017. The sample size of our study is fourteen (14) commercial banks of which five (5) are listed commercial banks at Dar es Salaam Stock Exchange (DSE) and nine (09) are non-listed commercial banks. The commercial banks included in our sample are those has transacted with government institutions and established on or before the year 2008 and their financial data can be easier accessed. The criteria for the selection of study sample is presented on Table 1 below.

Table 1. Criteria for sample selection

\begin{tabular}{llll}
\hline & Listed & Non Listed & Total \\
\hline Total banks as $31^{\text {st }}$ October 2017 & 06 & 34 & 40 \\
Less: & & & \\
Newly registered banks & $(01)$ & $(09)$ & $(10)$ \\
Banks with missing financial data & $(00)$ & $(16)$ & $(16)$ \\
Available commercial banks & 05 & 09 & 14 \\
\hline
\end{tabular}

Source: Researcher (2020).

\subsection{Data Sources}

Our study used secondary data to examine the relationship between the independent and dependent variables. The secondary data on the government deposits were gathered from the BOT. On the other hand commercial banks financial performance data were collected from respective commercial bank's audited annual reports from the year 2008 to 2017, and supplemented by the banks websites and DSE website.

\subsection{Government Deposits and Bank Financial Performance Variable Measurement and References}

Our study used financial performance as a dependent variable, this variable was measured by 
net interest margin (NIM). NIM is the commonly watched measure of the bank financial performance which refers to the difference between interest income and interest expenses as percentage of total assets. Therefore, if the bank is able to raise funds with liabilities that have low interest costs and is able to acquire assets with high interest income, the NIM will be high and the bank is likely to be profitable. On the other hand, if the interest cost of its liabilities rises relative to the interest earned on its assets, the NIM will fall and bank profitability suffer.

Table 2. Measurement of dependent variable

\begin{tabular}{|c|c|c|c|c|}
\hline $\mathrm{S} / \mathrm{N}$ & Variable & Measurement & \multicolumn{2}{|l|}{ References } \\
\hline \multirow[t]{2}{*}{1} & Net Interest Margin & Insert Income - Insert Expense & \multirow{2}{*}{$\begin{array}{l}\text { Obeid } \\
(2017)\end{array}$} & \multirow[t]{2}{*}{ Adeinat } \\
\hline & & Total Asset & & \\
\hline
\end{tabular}

Source: Researcher (2020).

The independent variable in our study is total amount of government deposit in Tanzania commercial banks.

Table 3. Measurement of independent variable

\begin{tabular}{llll}
\hline $\mathrm{S} / \mathrm{N}$ & Variable & Measurement & Reference \\
\hline 1 & Government & Natural log of total Government & Onuorah and Chigbu (2016) \& \\
& Deposit & Deposits & (Ndubuaku at el., 2017) \\
\hline
\end{tabular}

Source: Researcher (2020).

In our research, both the bank age and leverage were employed as controlling variables.

Table 4. Measurement of controlling variables

\begin{tabular}{llll}
\hline S/N & Variable & Measurement & Reference \\
\hline 1 & Bank Age & Natural log of age & D'Amato(2015) \\
2 & Leverage & Long term debt to total assets & Mwambuli(2015) \\
\hline
\end{tabular}

Source: Researcher (2020).

\subsection{Data Analysis and Model}

Our study data analysis was conducted by using both descriptive and inferential statistical measures. However in order to establish the relationship between the variables (independent and dependent), EVIEW 12 and STATA 16 Software were the tools that aid the analysis. Our research findings were presented using tables and figures. The simple linear regression model 
was used to explain the relationship of TSA on the financial performance of commercial banks in Tanzania.

$$
\mathrm{Y}_{\mathrm{t} 1}=\alpha+\beta \mathrm{X}_{\mathrm{t}}+\mathrm{C}+\mathrm{e}
$$

Whereby: -

$\mathrm{Y}_{\mathrm{t} 1}=$ Financial performance

$\alpha=$ The Intercept of the equation

$\mathrm{X}_{\mathrm{t}}=\mathrm{TSA}$

$\beta=$ Coffeeicient of TSA

$\mathrm{C}=$ Controlling variables

$\mathrm{e}=$ Error term

\section{Findings and Discussion of Results}

This section describes the study findings to fill the knowledge gap on the impact of TSA on the performance of commercial banks in Tanzania.

\subsection{Descriptive Statistics}

Descriptive measures of variables used in this study were presented on Table 5 below. The results showed that NIM had a mean of $7.8 \%$, this value presents an average financial performance of the commercial banks in Tanzania during 2008-2017. The mean of TSA was 14.77 this indicates that the commercial banks depend much on the government deposits to run their lending operations. Although dependency ratio were decreases on yearly basis i.e. government deposit over total commercial banks deposit ratio for 10 years was as follows (2008-2017; 47.11\%, 50.28\%, 49.11\%, 21.24\%, 21.89\%, 22.64\%, 20.13\%, 18.44\%, 16.91\% and $15.64 \%$ respectively). The average proportion of leverage is $79.16 \%$ this indicates the commercial banks are highly financed by external sources (debts) to run their lending operations, since the commercial banks acts as financial intermediation between borrowers and savers units. The bank's age of commercial banks in Tanzania had a mean of 3.15, this results suggest that the Tanzania banking sector is still at growing stage.

Table 5. Descriptive statistics

\begin{tabular}{lllll}
\hline & NIM & $\begin{array}{l}\text { GOVERNMENT } \\
\text { DEPOSIT }\end{array}$ & LEVERAGE & BANK_AGE \\
\hline Mean & 0.078055 & 14.77156 & 0.791566 & 3.145495 \\
Median & 0.065290 & 14.88860 & 0.821550 & 3.091042 \\
Maximum & 0.342800 & 15.05263 & 0.881010 & 4.304065 \\
Minimum & 0.004328 & 14.22232 & 0.465100 & 2.302585 \\
Std. Dev. & 0.048745 & 0.254772 & 0.099987 & 0.568918 \\
Observations & 140 & 140 & 140 & 140 \\
\hline
\end{tabular}

Source: EVIEW 12 Analysis of Data. 


\subsection{Regression Analysis}

The researchers conducted a multiple regression analysis using EVIEWS 12 software to assess the impact of TSA on the performance of commercial banks in Tanzania. Table 6 shows that linear regression test result of the TSA and financial performance in the Tanzania banking industry tested at 5\% level of significant. The coefficient of TSA is positive 0.010371 and the $p$ value (significant value) of TSA is 0.0001 that is less than 0.05 . This implies a significant positive relationship exists between TSA and financial performance in the Tanzania banking industry. The commercial banks will be affected since in the most cases they depend much on the government deposits to carter for bank liquidity which automatically fosters the banks to issue loans and engage in the business whereas they get their share through returns with interest as profit. The adoption of TSA will automatically affects lending capacities because their deposits have been declined. In addition to that, $\mathrm{Ng}$ 'winamira (2016) also provide that TSA was a quick decision with no time for commercial banks and several other business entities to prepare, it affected commercial banks greatly since they were entities responsible for facilitating the circulation of the cash that was generated in the economy. This will affect the stability and prosperity of most commercial banks because part of their liqudity ratio was affected and automatically become less functional and responsive to the clients and the market demands.

Table 6. Linear regression

\begin{tabular}{lllll}
\hline R Squared & \multicolumn{2}{l}{0.385027} & & \\
Adjusted R Squared & & 0.371462 & & \\
F-Statistic & & & \\
Prob (F-Statistic) & & 0.38268 & & \\
Number of Observations & 140 & & \\
\hline Variable & Coefficient & Std. Error & t-Statistic & Prob. \\
\hline Government deposit & 0.010371 & 0.002483 & 4.176236 & 0.0001 \\
Leverage & 0.460273 & 0.061677 & 7.462616 & 0.0000 \\
Bank age & -0.090054 & 0.022288 & -4.040550 & 0.0001 \\
Constant & -0.017962 & 0.093122 & -1.835899 & 0.0686 \\
\hline
\end{tabular}

Source: EVIEW 12 Data Analysis.

\section{Conclusion and Recommendations}

Our research explains the relationship between TSA and commercial banks financial performance. The data analyzed using the linear regression technique. Our results concluded that adoption of TSA has a significant positive effects on banks financial performance. This result is in line with Onuorah and Chigbu (2016) and theory of financial intermediation, which suggested that the adoption of TSA affect the performance of commercial banks. This significant impact imply that the Tanzania commercial banks were mostly depending on the 
government deposits to carter for liquidity of the banks and perform lending and other banking activities and operations. Our study will be useful to the banking industry, policy makers and stakeholders at large to have a better understanding on the adoption of TSA. Understanding the impacts of TSA on the financial performance of commercial banks in Tanzania is critical in understanding the economic growth and sustainable development of banking industry in Tanzania. The commercial banks should avoid over-reliance on government funds and source for funds from other sectors of the economy, rural banking should be aggressively undertaken to mobilize funds from the un-banked among rural residents.

The study recommends to the central bank as the regulator of the economy to make sure that it really fosters commercial banks to have stable business in the market which guarantees generation of sufficient income to correspond with sufficient liquidity. This is important because other opportunities which may provide Laissez-faire practices to the commercial banks in business undertakings must be eliminated to ensure total stability of the entities at all times.

Our research was limited by lack of previous empirical studies on the topic as it was just established on 2017 at the country level. Our study has been able to give room for further research due to the fact that the study only explored the pre effect of TSA on financial performance of commercial banks in Tanzania, it is therefore recommended that future researchers who might be interested in this area of study should expand the scope to include the post effects of TSA on financial performance of commercial banks in Tanzania.

\section{Reference}

Agbo, P. O., Jugu, Y. G., \& Okwoli, A. A. (2016). Effects of Treasury Single Account on Performance and Survival of Deposit Money Banks in Nigeria. International Journal of Management Science Research, 2(1), 185-198.

D'Amato, A. (2015). Risk-Taking in Cooperative Banks: Do Board Characteristics Matter? International Journal of Business and Social Science, 9(11), 80-90. https://doi.org/10.30845/ ijbss.v9n $11 \mathrm{p} 10$

Ighosewe, E. F., \& Ofor, N. T. (2017). Effect of Treasury Single Account (TSA) on Banks Performance in Nigeria, An Exploratory Study, Sahel Analyst. Journal of Management Sciences, 15, 32-49.

Lambe, I., \& Daniel, E. K. (2019). Effect of Treasury Single Account On The Performance Of Deposit Money Banks (DBMs) In Nigeria. In R. \& T. Department (Ed.) (pp. 237-256). Lagos, Nigeria: The Institute of Charted Accountants of Nigeria.

Mwambuli, E. L. (2015). What Determine Corporate Capital Structure in Developing Economies? Evidence from Eat African Stock MarketsRisk-Taking in Cooperative Banks: Do Board Characteristics Matter? Research Journal of Finance and Accounting, 12(6), 221-239.

Ndubuaku, V. C., Ohaegbu, O. K., \& Nina, N. M. (2017). Impact of Treasury Single Account on the Performance of the Banking Sector in Nigeria. IOSR Journal of Economics and Finance, 8(4), 8-15. https://doi.org/10.9790/5933-0804010815

Ng'winamira, R. (2016). Importance of Capital Adequacy to Commercial Banks. A Paper presented on induction ceremony of ACCE, UCC Campus., 31(5), 193-204. 


\section{Macrothink}

Obeid, R., \& Adeinat, M. (2017). Determinants of Net Interest Margin: An Analytical Study on the Commercial Banks Operating in Jordan (2005-2015). International Journal of Economics and Financial Issues, 7(4), 515-525.

Ogbonna, C. J., \& Amuji, H. O. (2018). Analysis of the Impact of Treasury Single Account on the Performance of Banks in Nigeria. Open Journal of Statistics, 8, 457-467. https://doi.org/10.4236/ojs.2018.83029

Olaoye, F. O., \& Talabi, O. A. (2019). Impact of Treasury Single Account (TSA) on the Financial Performance of Deposit Money Banks ( DMBs ) in Nigeria : A Pre-Post Analysis. Open Journal of Social Sciences, 7(5), 332-347. https://doi.org/10.4236/jss.2019.75026

Onuorah, A. C., \& Chigbu, E. E. (2016). Federal Government Treasury Single Account (TSA) Deposits and Commercial Banks Performance. Journal of Social and Management Sciences, 11(3), 01-13.

Pattanayak, S., \& Fainboim, I. (2011). Treasury Single Account: An Essential Tool for Government Cash Management. Working paper prepared by Sailendra Pattanayak and Israel Fainboim, Authorized for distribution by Carlo Cottarelli.

Sabo, A., Muhammad, S., \& Ka'oje, M. (2019). The Treasury Single Account (TSA) on Bank Liquidity: Fresh Evidence from Nigeria. East African Scholars Journal of Economics, Business and Management, 5(2), 256-259.

www.bot.go.tz (Accessed on: 15th May 2020).

\section{Copyrights}

Copyright for this article is retained by the author(s), with first publication rights granted to the journal.

This is an open-access article distributed under the terms and conditions of the Creative Commons Attribution license (http://creativecommons.org/licenses/by/4.0/). 